\title{
Effect of natural spices on the progression of microbial food spoilage in the steamed beans pudding, moin-moin
}

\author{
F. AYOADE *, A. OSHO, O.O. Adesanya, S.O. FAYEMI, N.E. OYEJIDE and G.I. OJO \\ Department of Biological Sciences, College of Natural Sciences, Redeemer's University, P.M.B 3005, \\ Redemption Camp Post Office, KM 46, Lagos-Ibadan Expressway, Redemption Camp, Ogun State, Nigeria. \\ *Corresponding author, E-mail: fayoade22@gmail.com
}

\begin{abstract}
Using a completely randomized block design, the progression of microbial food spoilage and the microbiological and sensory qualities of steamed cowpea paste (moin-moin) seasoned with onion, garlic, nutmeg and cinnamon was investigated. The total plate count was enumerated at approximately four hour intervals using Mueller-Hinton and Sabroaud dextrose agar for bacteria and fungal spoilage organisms respectively. Sensory evaluation was carried out using a 9-point hedonic scale. Results revealed no statistically significant difference in the progression of microbial spoilage. Eight bacterial species were isolated from the treatment samples as follows: Bacillus nealsoni, B. megaterium, B. pumilus, B marinus, Salimicrobium halophilum and Micrococcus varians. While 7 (seven) isolated fungi from the treatment samples are Gonatobotrys spp, Alternaria spp, Gymnoascus spp, Acremonium spp, Geotrichum spp, Oidiodendrum spp and Cladosporium spp. Untreated control and samples treated with nutmeg were preserved for the longest period of 23 hours. The present results show that moin-moin would spoil within 24 hours if kept at ambient temperature. The widely accepted reports of in-vitro anti-microbial effect of the spices was not observed in-vivo. Further work is needed on increasing the shelf-life of moin-moin and other similar foods.
\end{abstract}

(c) 2012 International Formulae Group. All rights reserved.

Keywords: Antimicrobial activity, in-vivo, flow diagram.

\section{INTRODUCTION}

The steamed beans pudding or moin-moin made from cowpea (Vigna unguiculata (L) Walp) is a popular meal in Nigeria and other West African Countries. It is common in many home diets, restaurants and ceremonial occasions. It is consumed by various tribes and creeds by virtue of its popularity among the few indigenous foods that are found on the menu at public eating places (Okoli, 2002). Moin-moin originated from West Africa, arising majorly out of the Nigerian culture.
In general, this product is mixed with oil, salt, onions, peppers, and other seasoning agents before it is steamed in either a metal / glass mould or banana leaves. The resulting product is then served either as a cool gel or as a warm pudding with either a grain or cereal like Jollof rice, fried rice, fried plantain or custard.

In Nigeria, legume processing into products like soymilk, soy cheese, cowpea cake and puddings (moin-moin) are common. Legumes belong to the family Leguminosae. In the tropics, they are the next important food 
crop after cereals (Uzoechina, 2009). They are sources of low-cost dietary vegetable proteins and minerals when compared with animal products such as meat, fish and egg (Apata and Ologhobo, 1997). Therefore indigenous legumes are an important source of affordable alternative protein to people with limited resources in many tropical countries most especially in Africa and Asia where they are predominantly consumed (Ihekoronye and Ngoddy 1985).

The dry cowpea bean (common form for West African consumers) contains on average $11 \%$ moisture, $23.85 \%$ protein, $2 \%$ lipids, $3.39 \%$ ash, $10.7 \%$ dietary fibre, and 48.94\% carbohydrates (Phillips, 1982; Phillips et al., 2003). Dried semi-finished legume products with low moisture like flours have good keeping qualities at ambient conditions when they are stored away from moisture. However, the freshly prepared products such as soymilk, soy-cheese, bean pudding (moinmoin) and cakes have short shelf-life of about a day or two at ambient condition. Research studies need to be conducted to develop low cost procedures for extending the shelf-life of these products so as to improve their keeping quality. Refrigeration, freezing and sophisticated preservative techniques which have high cost implication are usually not adopted by local processors.

Spoilage is a metabolic process that causes food to be undesirable or unacceptable for human consumption due to changes in sensory and nutritional characteristics (Doyle, 2007). The quality and safety of foods is one of the major concerns in the food industries because there is a high demand for fresher and minimally processed products. In particular, bacterial contamination of ready to eat products is of concern to human health. Antibacterial sprays or dips are available to overcome these contaminations (Entani et al., 1998). However, direct surface application of antibacterial substances has some limitations because the active substances could be neutralized, evaporated or diffused inadequately into the bulk of food (DeVere and Purchase, 2006).

Many food products require protection against microbial spoilage during their shelf life. The growing demand of consumers for safe and natural products, without chemical preservatives, has resulted in meticulous investigations by food authorities and researchers to assess the feasibility of kinder preservation techniques and to improve the microbial quality and safety of products, while also maintaining their good nutritional and organoleptic properties. Also, with the rise in bacterial resistance to antibiotics, there is considerable interest in the development of other classes of antimicrobials for the control of infection. Spices and essential oils that are traditionally used in cooking fall squarely into the category of edible natural products that may be used as safe food preservatives. The major antimicrobial components of spices and their essential oils are, for example, eugenol in cloves, allicin in garlic, cinnamic aldehyde and eugenol in cinnamon, carvacrol and thymol in oregano and thyme, and vanillin in vanilla beans. The antimicrobial activity of some essential oil components against food borne pathogens, including mycotoxinproducing fungi, has been confirmed (Ultee et al., 1998, 2000). In recent times, plant extracts have been developed and proposed for use in foods as natural antioxidants and/or antimicrobials (Hsieh et al, 2001).

The extract of traditional natural spices such as garlic have been shown to have a broad spectrum antibacterial activity, including effects on Escherichia, Salmonella, Staphylococcus, Streptococcus, Klebsiella, Proteus, Clostridium, Mycobacterium and Helicobacter species. In addition, certain oral streptococci and lactobacilli have been shown to be sensitive to garlic extract and a mouth wash containing garlic extract is more effective at reducing the total salivary bacterial count and the mutant streptococcal count (Kumar and Berwal, 1997; Groppo et al, 2002). Moreover, cinnamon infusions have been shown to inhibit several yeasts at a $10 \%$ 
concentration (Bidlack et al., 2000). Concentrations as low as 25 ppm of cinnamon essential oil inhibited germination of Mucor and Aspergillus spores after 6-8 hours (Sagdic, 2003; Shan et al., 2007). Hence, cinnamon extracts could be used as antifungal agents in products which have a compatible flavour such as bakery products where fungi are the most common spoilers.

Myristica fragrans Houtt. (Myristicaceae), which is known as pala in Indonesia, luk jan in Thailand, nikuzuku in Japan, and commonly nutmeg or mace, is another food condiment that has been reported to show antibacterial activity against cariogenic Streptococcus mutans (Chao et al., 2000).

A combined use of antimicrobials has the potential of increasing the antimicrobial effect, reduce side effects and decrease microbial resistance to antimicrobials. Synergistic effects of combined utilization of different essential oils were confirmed and their improved antimicrobial effect without raising their concentrations has been reported (Chao et al., 2000). For example combined extracts prepared from cinnamon (Cinnamomum cassia), Chinese chive (Allium tuberosum), and corni fructus (Cornus officinalis) exhibited a better inhibition on growth of $E$. coli than potassium sorbate (Mau et al., 2001). Adding cinnamon oil and clove oil added at $2 \%$ in potato dextrose agar (PDA) completely inhibited the growth of seven mycotoxigenic moulds (Aspergillus flavus, Aspergillus parasiticus, Aspergillus ochraceus, Penicillium spp. M46, $P$. roqueforti, $P$. patulum, and $P$. citrinum) for up to 21 days and could also inhibit the growth of yeasts (Elgayyar et al., 2000).

The present work reports the effect of the application of natural spices on the progression of microbial food spoilage in the steamed bean pudding, moin-moin. Since compatibility with taste is almost as important with the ability to preserve the shelf life of food, an assessment of the organoleptic appeal of the different combinations of the natural spices and their ability to preserve food from microbial spoilage formed the focus of this study.

\section{MATERIALS AND METHODS}

Preparation of moin-moin paste

Onions, garlic, cinnamon and nutmeg were purchased from a local market on Redemption Camp and moin-moin was prepared based on the schedule shown in the flow diagram below (Figure 1). Cooking was done in the Home Economics kitchen of Redeemer's University. After dehulling, 2.67 $\mathrm{kg}$ of black eyed beans was blended with $90 \mathrm{~g}$ of Scotch Bonnet (Ata rodo) and $200 \mathrm{~g}$ of red bell pepper (Tatase) using $3 \frac{1}{3}$ cups of water ( 1 cup $=250 \mathrm{ml})$. After blending $19.5 \mathrm{~g}$ of maggi, $44.5 \mathrm{~g}$ of salt, 2 cups of groundnut oil and an extra 2 cups of water was added to reduce the thicknesss. A simple kitchen blender was used to blend the beans and spices.

\section{Preparation of the spices}

Onions : $500 \mathrm{~g}$ of medium size onion bulbs was blended with $3 / 4$ cup of water. Garlic : $200 \mathrm{~g}$ of garlic was blended with $3 / 4$ cup of water. The Nutmeg was reduced to powder using a grater and the Cinnamon was purchased already processed into powder (Spice Supreme ${ }^{\mathrm{TM}}$ ).

\section{Moin-moin samples Onion}

2 cups of the Moin-moin paste was mixed with $3 / 4$ cup of the blended onions, the preparation was then dispensed into 5 small transparent nylons and labelled properly.

\section{Garlic}

2 cups of moin-moin paste was mixed with $1 / 3$ cup of the blended garlic, the preparation was then dispensed into 5 small transparent nylons and labelled properly.

Nutmeg

2 cups of the moin-moin paste was mixed with 1 tea spoon $(5 \mathrm{~g})$ of nutmeg powder, the preparation was then dispensed 
into 5 small transparent nylons and labelled properly.

\section{Cinnamon}

2 cups of the moin-moin paste was mixed with 1 tea spoon of cinnamon powder, the preparation was then dispensed into 5 small transparent nylons and labelled properly.

\section{Control}

Negative: only 2 cups of the moin-moin paste was dispensed into 5 small transparent nylons and labelled properly.

The different sample preparations were then steamed for 40 minutes at $100{ }^{\circ} \mathrm{C}$ and allowed to cool. Sensory evaluation was carried out on the samples and the remaining samples were kept at ambient conditions to monitor the spoilage.

\section{Sensory evaluation}

A randomly selected 8 member panel consisting of interested Redeemer's University students was used to evaluate the product (moin-moin). The panel tested the products by eating it, then rinsing their mouth with water after testing each product and ranked them on the basis of appearance, colour, flavour, taste and overall acceptability on a 9- point hedonic scale. $9=$ Like extremely; $8=$ Like very much; $7=$ Like moderately; $6=$ Like slightly; $5=$ Neither like nor dislike; 4 = Dislike slightly; $3=$ Dislike moderately; 2 = Dislike very much; $1=$ Dislike extremely. The participants in the sensory evaluation have tasted moin-moin at least more than ten times before participation in the tasting event was administered; moin-moin being part of their regular diet and as such are used to the widely acceptable taste of moinmoin. The raw scores were assembled and the mean scores used to calculate the Analysis of Variance (ANOVA). Independent $T$ test was conducted to check if there was a significant difference between the control moin-moin and every other observed sample of moin-moin.

\section{Microbial analysis}

One gram of each moin-moin sample was aseptically transferred into a sterile testtube containing $9 \mathrm{ml}$ of sterile water, thoroughly shaken together and serially diluted up to $10^{-10}$ dilution. $1 \mathrm{ml}$ of this dilution was inoculated onto sterile MuellerHinton Agar (MHA) and Saboraud dextrose agar (SDA) for bacteria and fungi respectively, the MHA plates were then incubated for $18-24 \mathrm{hrs}$ at $37^{\circ} \mathrm{C}$ and the SDA plates for 3-4 days at $30{ }^{\circ} \mathrm{C}$. Pure cultures were then obtained by re-streaking into fresh medium employing standard methods. The isolates were screened based on the size, colony aspect ratio, colour; Gram's staining reactions, and biochemical tests.

For the isolation of bacteria, MuellerHinton Agar (MHA) was used as the growth medium. Using the spread plate technique, 0.1 $\mathrm{ml}$ of $10^{-10}$ diluent inoculum was dispensed into a sterile Petri dish containing solidified sterile medium. The inoculum was then spread aseptically on the surface of the respective media using a flame sterilized bent glass rod (spreader). The plate was then incubated at 37 ${ }^{\circ} \mathrm{C}$ for $18-24$ hours after which growth occurs and was then sub cultured to get pure cultures. Representative samples were taken from the respective spice preparations and plated out by spread plate method at approximately four hour intervals. The distinct colonies on the plates were counted using a colony counter and the mean bacteria count per $\mathrm{ml}$ was calculated using the formula below:

Mean bacteria count $/ \mathrm{ml}=\frac{\text { AVCFUEP }}{\text { VSDUA }} \times$ DF

AVCFUEP: average value of colony forming units on enumerated plates

VSDUA: Volume of sample dispensed unto agar

DF: dilution factor.

To study the effect of natural spices on the fungal species, isolation was performed in a similar manner as bacteria isolation but 
using Saboraud Dextrose Agar (SDA) medium. These were incubated at $27{ }^{\circ} \mathrm{C}$ for five days. Hereafter, sub-culturing ensued in order to obtain pure cultures of isolates. Identification and characterization of the microorganisms were subsequently performed based on cultural and morphological characteristics of colonies and biochemical characteristics of the isolates such as methyl red, Vogues-Praskauer, Citrate, Urease, Indole, Motility, Catalase, Oxidase, and sugar fermentation tests.

\section{RESULTS}

Table 1 shows the mean bacteria count of the Moin-moin samples with different spices kept for 27 hours at room temperature. Representative data of samples taken from the respective spice preparations and plated out by spread plate method at the $16^{\text {th }}$ hour, $23^{\text {rd }}$ hour and the $27^{\text {th }}$ hour respectively are shown in Table 1. At the $23^{\text {rd }}$ hour of incubation the samples with cinnamon and garlic had begun to give off a bad odour with the softening of some of their parts, the samples also became slimy to touch. On the other hand, samples with onions did not give off a bad smell but were slightly slimy to touch. The samples with nutmeg and the control with no spice at all kept the longest because as at the $23^{\text {rd }}$ hour they were still firm with no uncharacteristic change in smell. The results show that the control samples kept for the longest period of time, showing the lowest bacterial count when samples were evaluated after 27 hours. By the $27^{\text {th }}$ hour, a decline in bacterial count was observed for all treatments including the control (Table 1). When the same samples were evaluated at the above stated time intervals for mean fungal count, no differences were observed between the treatments and the control (Table 2).

Tables 3 and 4 show the number of bacterial and fungal species that were isolated from all the moin-moin preparations, including the control treatment. In all, 8 (eight) bacterial species were isolated from the samples as follows: Bacillus nealsoni, $B$. megaterium, B. pumilus, B marinus, Salimicrobium halophilum and Micrococcus varians. On the other hand, the 7 (seven) fungal species isolated were identified as Gonatobotrys spp, Alternaria spp, Gymnoascus spp, Acremonium spp, Geotrichum spp, Oidiodendrum spp and Cladosporium spp.

Table 5 shows the frequency of reoccurrence of spoilage bacteria that were found to reoccur in the various treatments of Moin-moin samples. After 16 hours Bacillus nealsonii was found in the garlic treatment, showing that the other isolates were inhibited by this particular species in the presence of garlic. B. lentus, B. nealsonii and B. marinus reoccurred in the onion treatment, while $B$. nealsonii and $B$. pumilus were found in nutmeg treatment. B. lentus, B. pumilus and $B$. marinus were present in the cinnamon treatment, while only $B$. lentus and $B$. nealsonii reoccurred in the control. After 16 hours the isolates with the highest frequency was $B$. nealsonii occurring in 4 of the 5 treatments sparing only the sample treated with cinnamon. Fungi isolates that reoccurred after 16 hours were; Gonatobotrys species, Alternaria species, Acremonium species and Cladosporium species with Cladosporium species occurring twice in the onion treated sample and the control (Table 6).

Sensory evaluation studies revealed that in all cases the moin-moin samples were still palatable after the spices were added. The control proved to be the most palatable followed by the onion treated sample; the sample treated with nutmeg was less palatable than the onion treatment and was closely followed by the sample treated with garlic. Cinnamon was the most unpalatable with a value of 3.5 which stands for 'Dislike moderately'. The statistical analysis show that there was no significant difference between the different treatments and the control when compared based on all the measured organoleptic parameters (Table 7). 


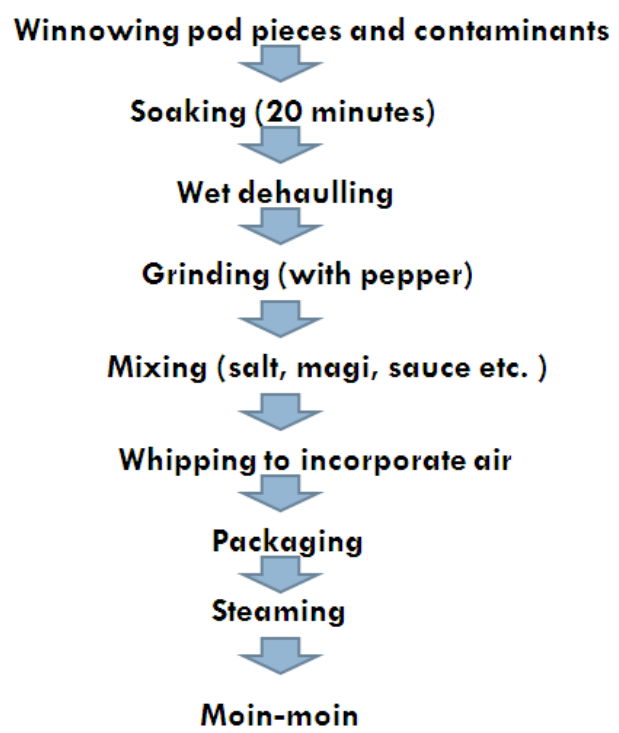

Figure 1: Flow diagram for the processing of cowpea seeds into moin-moin.

Table 1: Bacterial count for moin-moin samples kept at ambient conditions for 27 hours.

\begin{tabular}{lccc}
\hline Sample & $\begin{array}{c}\text { Mean bacteria count } \\
\text { after 16 hours } \\
(\mathbf{C F U} / \mathbf{m l})\end{array}$ & $\begin{array}{c}\text { Mean bacteria count } \\
\text { after 23 hours } \\
(\mathbf{C F U} / \mathbf{m l})\end{array}$ & $\begin{array}{c}\text { Mean bacteria count } \\
\text { after 27 hours } \\
(\mathbf{C F U} / \mathbf{m l})\end{array}$ \\
\hline Control & $5.62 \times 10^{6}$ & $3.55 \times 10^{8}$ & $0.15 \times 10^{8}$ \\
Garlic & $2.29 \times 10^{6}$ & $\mathrm{TNTC}$ & $2.15 \times 10^{8}$ \\
Onion & $0.24 \times 10^{6}$ & $0.15 \times 10^{8}$ & $0.75 \times 10^{8}$ \\
Nutmeg & $0.80 \times 10^{6}$ & $0.15 \times 10^{8}$ & $0.45 \times 10^{8}$ \\
Cinnamon & $0.73 \times 10^{6}$ & $20.2 \times 10^{8}$ & $0.40 \times 10^{8}$ \\
\hline
\end{tabular}

TNTC $=$ Too numerous to count.

$\mathrm{CFU} / \mathrm{ml}=$ Colony forming units/millilitres.

Table 2: Fungi colony count for moin-moin samples kept at ambient conditions for 27 hours.

\begin{tabular}{lccc}
\hline Sample & $\begin{array}{c}\text { Fungi colony } \\
\text { count after 16 } \\
\text { hours }\end{array}$ & $\begin{array}{c}\text { Fungi colony } \\
\text { count after 23 } \\
\text { hours }\end{array}$ & $\begin{array}{c}\text { Fungi colony count after 27 } \\
\text { hours }\end{array}$ \\
\hline Control & 1 & 1 & 2 \\
Garlic & --- & 1 & 2 \\
Onion & 1 & 2 & 1 \\
Nutmeg & 2 & 2 & 1 \\
Cinnamon & 1 & 1 & 2 \\
\hline
\end{tabular}


Table 3: Identification of isolated bacteria.

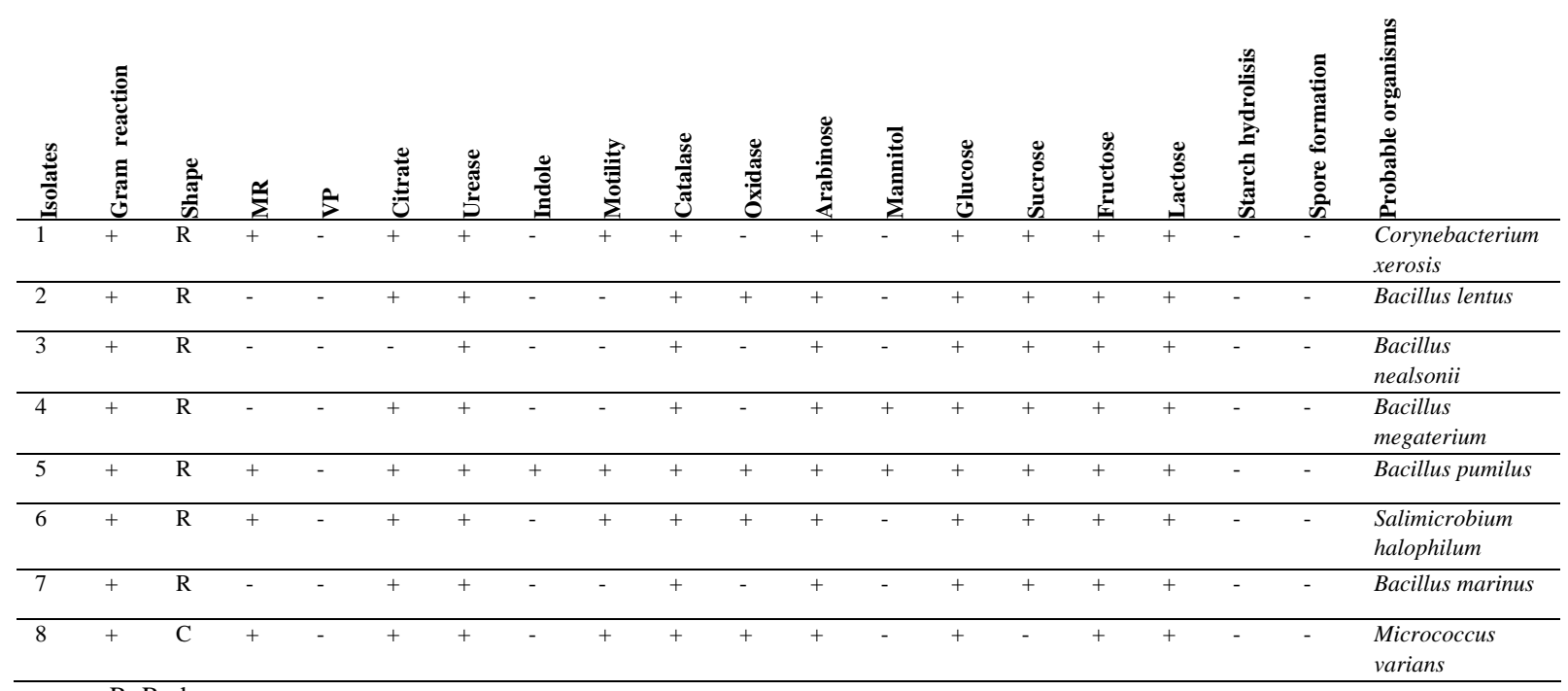

R: Rods.

C: Cocci.

Table 4: Identification of fungal isolates.

\begin{tabular}{lll}
\hline Isolates & $\begin{array}{l}\text { Morphological characteristics } \\
\text { Isolate 1 }\end{array}$ & $\begin{array}{l}\text { Suspected organism } \\
\text { reverse plate. }\end{array}$ \\
\hline Isolate 2 & $\begin{array}{l}\text { Black mycelium with white edges, black on the } \\
\text { reverse plate. }\end{array}$ & Alternaria species \\
\hline Isolate 3 & $\begin{array}{l}\text { Profuse white mycelia growth with orange } \\
\text { colourations, white on reverse plate. }\end{array}$ & Gymnoascus species \\
\hline Isolate 4 & Wooly white mycelium, cream on reverse plate. & Acremonium species \\
\hline Isolate 5 & Fuzzy white mycelium, white on reverse plate. & Geotrichum species \\
\hline Isolate 6 & $\begin{array}{l}\text { Cottony white mycelium, white on reverse } \\
\text { plate. }\end{array}$ & Oidiodendrum species \\
\hline Isolate 7 & $\begin{array}{l}\text { Pale green mycelium with white edges, cream } \\
\text { on the reverse plate. }\end{array}$ & Cladosporium species \\
\hline
\end{tabular}


F. AYOADE et al. / Int. J. Biol. Chem. Sci. 6(6): 5030-5041, 2012

Table 5: Bacterial isolates and their frequency of occurrence in moin-moin samples kept at ambient conditions.

\begin{tabular}{|c|c|c|c|c|c|c|c|c|c|c|c|c|c|c|c|c|c|c|}
\hline \multirow[b]{2}{*}{ Isolates } & \multicolumn{6}{|c|}{ After 16 hours } & \multicolumn{6}{|c|}{ After 23 hours } & \multicolumn{6}{|c|}{ After 27 hours } \\
\hline & $\mathbf{A}$ & $\mathbf{B}$ & $\mathbf{C}$ & $\mathbf{D}$ & $\mathbf{E}$ & $\begin{array}{c}\text { Frequency } \\
\text { No. }(\%)\end{array}$ & $\mathbf{A}$ & $\mathbf{B}$ & $\mathbf{C}$ & $\mathbf{D}$ & $\mathbf{E}$ & $\begin{array}{c}\text { Frequency } \\
\text { No. }(\%)\end{array}$ & $\mathbf{A}$ & $\mathbf{B}$ & $\mathbf{C}$ & D & $\mathbf{E}$ & $\begin{array}{c}\text { Frequency } \\
\text { No. }(\%)\end{array}$ \\
\hline Bacillus lentus & - & + & - & + & + & $3(60 \%)$ & - & + & - & + & + & $3(60 \%)$ & + & + & + & + & + & $5(100 \%)$ \\
\hline $\begin{array}{l}\text { Bacillus } \\
\text { nealsonii }\end{array}$ & + & + & + & - & + & $4(80 \%)$ & + & - & - & + & - & $2(40 \%)$ & - & - & - & - & - & 0 \\
\hline $\begin{array}{l}\text { Bacillus } \\
\text { pumilus }\end{array}$ & - & - & + & + & - & $2(40 \%)$ & - & - & - & - & - & 0 & + & - & - & + & - & $2(40 \%)$ \\
\hline $\begin{array}{l}\text { Salimicrobium } \\
\text { halophilum }\end{array}$ & - & - & - & - & - & 0 & + & - & - & + & - & $2(40 \%)$ & - & - & - & - & - & o \\
\hline $\begin{array}{l}\text { Bacillus } \\
\text { marinus } \\
\end{array}$ & - & + & - & + & - & $2(40 \%)$ & - & - & + & - & + & $2(40 \%)$ & - & - & - & - & - & 0 \\
\hline $\begin{array}{l}\text { A :Garli } \\
\text { B : Onio } \\
\text { C }: \text { Nutn } \\
\text { D : Cinn } \\
\text { E : Cont } \\
-: \text { Abse } \\
+: \text { Prese }\end{array}$ & & & & & & & & & & & & & & & & & & \\
\hline
\end{tabular}




\section{F. AYOADE et al. / Int. J. Biol. Chem. Sci. 6(6): 5030-5041, 2012}

Table 6: Fungal isolates and their frequency of occurrence in moin-moin samples kept at ambient conditions.

\begin{tabular}{|c|c|c|c|c|c|c|c|c|c|c|c|c|c|c|c|c|c|c|}
\hline \multirow[b]{2}{*}{ Isolates } & \multicolumn{6}{|c|}{ After 16 hours } & \multicolumn{6}{|c|}{ After 23 hours } & \multicolumn{6}{|c|}{ After 27 hours } \\
\hline & $\mathbf{A}$ & B & $\mathbf{C}$ & D & $\mathbf{E}$ & $\begin{array}{c}\text { Frequency } \\
\text { No. }(\%)\end{array}$ & $\mathbf{A}$ & B & $\mathbf{C}$ & D & $\mathbf{E}$ & $\begin{array}{c}\text { Frequency } \\
\text { No. }(\%)\end{array}$ & $\mathbf{A}$ & B & $\mathbf{C}$ & D & $\mathbf{E}$ & $\begin{array}{c}\text { Frequency } \\
\text { No. }(\%)\end{array}$ \\
\hline $\begin{array}{l}\text { Gonatobotrys } \\
\text { species }\end{array}$ & - & - & + & - & - & $1(20 \%)$ & - & - & - & - & - & $\mathbf{0}$ & - & - & - & + & - & $1(20 \%)$ \\
\hline $\begin{array}{l}\text { Alternaria } \\
\text { species }\end{array}$ & - & + & - & - & - & $1(20 \%)$ & - & - & - & - & - & $\mathbf{0}$ & - & - & - & - & - & $\mathbf{0}$ \\
\hline $\begin{array}{l}\text { Gymnoascus } \\
\text { species }\end{array}$ & - & - & - & - & - & $\mathbf{0}$ & - & - & - & - & - & $\mathbf{0}$ & - & - & + & - & - & $1(20 \%)$ \\
\hline $\begin{array}{l}\text { Acremonium } \\
\text { species }\end{array}$ & - & - & - & + & - & $1(20 \%)$ & + & - & - & - & + & $2(40 \%)$ & - & - & - & - & - & $\mathbf{0}$ \\
\hline $\begin{array}{l}\text { Geotrichum } \\
\text { species }\end{array}$ & - & - & - & - & - & $\mathbf{0}$ & - & - & - & - & - & $\mathbf{0}$ & + & - & - & - & + & $2(40 \%)$ \\
\hline $\begin{array}{l}\text { Oidiodendrum } \\
\text { species }\end{array}$ & - & - & - & - & - & $\mathbf{0}$ & - & + & + & + & + & $4(80 \%)$ & + & + & + & + & + & $5(100 \%)$ \\
\hline $\begin{array}{l}\text { Cladosporium } \\
\text { species }\end{array}$ & - & + & - & & + & $2(40 \%)$ & - & - & - & - & - & 0 & - & - & - & - & - & $\mathbf{0}$ \\
\hline $\begin{array}{l}\text { A : Garlic } \\
\text { B : Onion } \\
\text { C : Nutmeg } \\
\text { D : Cinnamon } \\
\text { E : Control.; - : }\end{array}$ & & & & & & & & & & & & & & & & & & \\
\hline
\end{tabular}


Table 7: Sensory evaluation of moin-moin samples.

\begin{tabular}{llllll}
\hline Samples & Appearance & Colour & Flavour & Taste & $\begin{array}{l}\text { Overall } \\
\text { Acceptability }\end{array}$ \\
\hline $\begin{array}{l}\text { Control (without } \\
\text { any spice) }\end{array}$ & 8.500 & 8.250 & 8.500 & 8.250 & 8.500 \\
\hline Garlic & 7.500 & 6.875 & 4.250 & 4.125 & 5.500 \\
\hline Onion & 8.375 & 8.250 & 7.875 & 7.500 & 7.875 \\
\hline Nutmeg & 6.750 & 7.000 & 4.500 & 4.750 & 5.750 \\
\hline Cinnamon & 4.250 & 4.250 & 3.875 & 3.5 & 4.125 \\
\hline $\begin{array}{l}\text { The result obtained from the two- way ANOVA conducted on the mean of all the parameter shows the F statistical } \\
\text { value of "0"(.), which can in no way be greater than the tabulated Critical F value of 4.175 so we conclude that there }\end{array}$ \\
$\begin{array}{l}\text { is no significant difference between the mean values of all the spices in all measurement parameter (Appearance, } \\
\text { Colour, Flavour, Taste, Overall acceptability). T test was conducted to confirm the significant difference between the } \\
\text { control and each of the other samples individually; the results show no significant difference between the control and } \\
\text { each of the other samples. }\end{array}$
\end{tabular}

\section{DISCUSSION}

Although natural spices such as Garlic, Onion, Nutmeg and Cinnamon which were used in this study have been proven to have antimicrobial activities in vitro (Gutierrez et al., 2008; Mau et al., 2001), the present results show no significant difference in the progression of microbial spoilage for all treatments including the control samples. The samples with nutmeg and the control with no spice at all seemed to keep the longest because as at the $23^{\text {rd }}$ hour they were still firm with no uncharacteristic change in smell, colour and texture. This may be due to the low protein content of nutmeg coupled with all its many antimicrobial properties mentioned earlier (Janssen et al., 1990). The absence of any spice in the control sample could be the reason it kept slightly longer as there were no other sources of nutrient for the microbes to utilize. These spices were added in their crude mixtures, so in addition to their antimicrobial compounds some other compounds in them e.g. protein compounds, might encourage the growth of microbes and this could overshadow its antimicrobial effect on the microbes. Moreover, the sustained heat used in cooking the moin-moin for 40 minutes perhaps had a suppressing effect on the microbial properties of these spices.
Moin-moin usually has a high moisture and protein content which facilitates the growth of microorganism and encourages spoilage. At the $27^{\text {th }}$ hour, there was a decrease in the microbial content in all the samples; this could be attributed to the lowering of the $\mathrm{pH}$ causing the medium to be more acidic and unfavourable for the growth and multiplication of bacteria and some fungi, this corroborates reports by Adegunloye et al., (2006).

The present study reveals that moinmoin would usually spoil after 24 hours if kept at ambient temperature, this study attempted to prolong the shelf life of moinmoin using natural spices. The spices however, seemed to increase the deterioration of the food. Apart from the control which lasted up to 23 hours, the moin-moin sample treated with nutmeg also kept for about 23 hours. Further work should be done on prolonging the shelf-life of moin-moin and other similar foods using safe but effective methods.

\section{ACKNOWLEDGEMENTS}

The authors acknowledge the technical support provided by Mrs. O.O. Lawson of the Home economics Department of the 
Redeemer's University in preparation of the moin-moin flow diagram.

\section{REFERENCES}

Adegunloye DV, Agarry OO, Adebolu TT, Adetuyi FC. 2006. Effect of leaf packaging on the microbiological assessment of some food items. African Journal of Biotechnology, 5(5): 445-447.

Apata DF, Ologhobo AD. 1997. Trypsin inhibitor and the other anti-nutritional factors in tropical legume seeds. Tropical Science, 37:52-59.

Bidlack WR, Omaye ST, Meskin MS, Topham D. 2000. Phytochemicals as Bioactive Agents. Technomic Publishing Company: Lancaster, UK; 106-110.

Chao SC, Young DG, Oberg CJ. 2000. Screening of inhibitory activity of essential oils on selected bacteria, fungi and viruses. Journal of Essential Oil Research, 12(5): 639-649.

DeVere E, Purchase D. 2006. Effectiveness of domestic antibacterial products in decontaminating food contact surfaces. Food Microbiology, 24(4): 425-430.

Doyle MP, Sperber WH. 2009. Compendium of the microbiological spoilage of foods and beverages. In Food Microbiology and Safety. Springer: USA; 8-15.

Elgayyar M, Draughon FA, Golden DA, Mount JR. 2001. Antimicrobial activity of essential oils from plants against selected pathogenic and saprophytic microorganisms. Journal of Food Protection, 64(7): 1019-1024.

Entani E, Asai M, Tsujihata S, Tsukamoto Y, Ohta M. 1998. Antibacterial action of vinegar against food-borne pathogenic bacteria including Escherichia coli 0157:H7. J. Food Protection, 61(8): 953959.

Groppo FC, Ramacciato JC, Simoes RP, Florio FM, Sartoratto A. 2002.
Antimicrobial activity of garlic, tea tree oil, and chlorhexidine against oral microorganisms. Int Dent. J., 52: 433437.

Gutierrez J, Barry-Ryan C, Bourke P. 2008. The antimicrobial efficacy of plant essential oil combinations and interactions with food ingredients. International Journal of Food Microbiology, 124: 91-97.

Hsieh PC, Mau JL, Huang SH. 2001. Antimicrobial effect of various combinations of plant extracts. Food Microbiology, 18: 35-43.

Ihekoronye AI, Ngoddy PO. 1985. Integrated Food Science and Technology for Tropics. Macmillan Publishers Ltd: London; 1-284.

Janssen J, Laekeman GM, Peiters LA, Totte J, Herman AG, Vlietinck AJ. 1990. Nutmeg oil: identification and quantification of its most active constituents as inhibitors of platelet aggregation. J. Ethnopharmacol., 29: $179-188$.

Kumar M, Berwal JS. 1998. Sensitivity of food pathogens to garlic (Allium sativum). Journal of Applied Microbiology, 84: 213-215.

Mau JL, Chen CP, Hsieh PC. 2001. Antimicrobial effect of extracts from Chinese chive, cinnamon, and corni fructus. Journal of Agricultural and Food Chemistry, 49: 183-188.

Okoli PI. 2002. Economic analysis of street food vending in Anambra State. PhD Thesis University of Nigeria, Nsukka, p. 146.

Phillips RD. 1982. Preparation and composition of a dry-milled flour from cowpeas. Journal of the American Oil Chemists Society, 59(8): 351-353.

Phillips RD, McWatters KH, Chinnan MS, Hung YC, Beuchat LR, Sefa-Dedeh S, Sakyi-Dawson E, Ngoddy P, Nnanyelugo 
D, Enwere J, Komey NS, Liu KS, MensaWilmot Y, Nnanna IA, Okeke C, Prinyawiwatkul W, Saalia FK. 2003. Utilization of cowpeas for human food. Field Crops Research, 82(2-3): 193-213.

Sagdic O, Karahan AG, Ozcan M, Ozkan G. 2003. Effect of some spice extracts on bacterial inhibition. Food Science and Technology, 9(5): 353-358.

Shan B, Cai Y, Brooks JD, Corke H. 2007. Antibacterial properties and major bioactive components of cinnamon stick (Cinnamomum burmannii): Activity against foodborne pathogenic bacteria. $J$. Agric. Food Chem., 55: 5484-5490.
Ultee A, Gorris LMG, Smid EJ, 1998. Bactericidal activity of carvacrol towards the food-borne pathogen Bacillus cereus. Journal of Applied Microbiology, 85: 211- 218 .

Ultee A, Slump RA, Steging G, Smid EJ, 2000. Antimicrobial activity of carvacrol toward Bacillus cereus on rice. Journal of Food Protection, 63: 620- 624.

Uzoechina OB. 2009. Nutrient and antinutrients potentials of brown pigeon pea (Cajanus cajan var bicolor) seed flours. Nigerian Food Journal, 27: 10-16. 